\title{
Corporate Social Responsibility, practice of observance and Spending as per the Companies Act, 2013
}

\author{
G.Silpa, Prof. DV Ramana, Dr. T. Narayana Reddy
}

\begin{abstract}
Corporate social responsibility is not new to India. This charitable action of the companies, however, is now blended with a mandatory constraint. The paper discuss about the provisions of the CSR norms as per the new Companies Act 2013, the process of its implementation, responsibilities of the company board and the CSR committee, list of activities that qualify for the CSR fulfillment, and penalties for breach. The paper also discusses the perceived influence against mandatory CSR, industry response, the issue of anchoring CSR spending to the minimum mandatory requirement, estimate of the scale of total CSR spending, and the Channels of CSR spending by companies.
\end{abstract}

Keywords: Corporate Social Responsibility, Companies Act,2013

\section{Introduction}

The concept of social responsibility is not alien to Indian soil. As a matter of fact, it is deeply rooted in the Indian Culture. With time to time with socio-economic changes the adoption of concept has evolved. Earlier the evolution was rotating around the axis of the religious belief and culture and in modern time, it is being widely accepted as a central strategic management tool or a value based management concept.

During the Vedic period CSR was centered on - Do and Don'ts of the socially desirable and good moral behavior. It was more a social responsibility concept led by spiritual leaders through spiritual literatures. Social responsibility transformed in to the leaders or leadership responsibility during the Post Vedic and Medieval phase. During that time kings enforced the basic laws of socially responsible behavior and also tried to introduce the fair practices in the business through legal control. Few of the leaders also worked towards the development of the social health and infrastructure in India. In a way Social responsibility concept was more driven by individual king's thought and leadership style. Immediately after the independence in democratic India, political leaders had a very specific social problems and challenges arisen after independence and partition of the county. All the attempts were very focused towards to control the situation. Formulation and implementation of fair business practices and legal laws was a major turnaround. Due to the poor economic conditions political parties also started involving and drawing support from the business leaders and corporate firms, thus we can say Social responsibility of business started getting transformed to Corporate Social Responsibility gradually during those days. At present the country is one among the fastest economically developing country of the world and Corporate Social Responsibility has been one of the very important business dimension and leadership concept in the current day`s business.

The pure voluntary activity of Indian CSR has recently been diverted with a mandatory element. Distinct in some other countries such as Australia, Denmark, Norway, and Sweden, where only the CSR reporting is mandatory, India is now the only country in the world where both coverage and spending has become mandatory. In this framework, the paper outlines the exact mandatory nature of the new law as applicable to certain companies, the process to implement the mandatory CSR activities, categories of activities that get covered under CSR, penalties for not complying with the provisions, a likely impact of the mandatory norms on the industry in general and on CSR spending in particular, and, finally, the possible strategic channels for companies to engage in CSR activities in future.

\subsection{The Law}

\section{The Law And Company Responsibilities}

Effective 1 April 2014, India"s newly amended Companies Act 2013 (MCA, 2013) makes it mandatory for certain companies, private limited or public limited, listed or unlisted, to spend a certain minimum amount on corporate social responsibility (CSR) activities. The Act applies to companies which have had a net profit of Rs. 5 crore or more or net worth of Rs. 500 crore or more or a turnover of Rs. 1000 crore or more in any financial year [Section 135(1)]. Such companies must spend a minimum of 2 per cent of the average net profit made during the three immediately preceding financial years (Section 135(5)]. The Act applies to a holding company, its subsidiary, and even a foreign company with a branch or project office in India [Section 2(42)]. As per Section 198 of the Act, in calculating net profit, among many other things, depreciation and interest on loans and debentures will be deducted but the income tax payable by the company will not be. 
Corporate Social Responsibility, practice of observance and Spending as per the Companies...

\subsection{Formation of CSR Committee}

Every company that meets the net profit, net worth, or turnover criteria of the Act has to constitute a CSR Committee of its Board. The Committee must consist of 3 or more members from the directors of the Company Board. Moreover, at least one of the members of the committee has to be an independent director. While an unlisted or a private limited company is exempted from having an independent director as a member, a private limited firm may have only 2 member directors in the Committee. A foreign firm may have 2 members, comprising of one resident in India [Section 380(d)] and another nominated by foreign firm. If a company ceases to be covered under the net profit or net worth or turnover criteria of the Act for three preceding financial years, then it is under no obligation to constitute a CSR committee of the Company Board (MCA, 2014b).

\subsection{Responsibilities of CSR Committee}

The CSR Committee thus constituted must formulate and recommend a CSR Policy for the company to the Company Board. The CSR Policy must indicates the activities to be undertaken by the company as per Schedule VII (see below), recommend the amount of expenditure to be incurred on the activities, institute a transparent monitoring mechanism for the implementation of the policy, and monitor the CSR policy from time to time.

\subsection{Mandatory Reporting by the Board}

A report by the Board of Directors must be attached to the statements laid before the general meeting of the company disclosing issues related to CSR. This will include declaring composition of the CSR Committee and due approval and disclosure of the policy contents. The report will also contain details of such policy and implementation initiatives already undertaken during the year. A sample format of the annual CSR report is provided in the annexure to the notification of CSR rules (MCA, 2014b). Moreover, such information will be placed on the company"s website. If the company fails to spend the legally required amount on CSR activities, the Board must specify reasons for not spending. The issues are covered in Sections 134(3)(o), 135(2), 135(4)(a), and 135(5) of the Act.

\subsection{Responsibilities of the Board}

The Board must ensure that the activities included in the CSR policy are undertaken by the company, the expenditure by the company meets the 2 per cent requirement as per the Act, and that the company gives preference to local area and areas around which it operates [Section 135(4b) \& (5)]. The Board may decide to undertake CSR activities through a registered trust or a registered society or a company established by the company or its holding or subsidiary or associate company under Section 8 of the Act. If the CSR activities are done through a trust/society/company which is not established by the company, its holding or subsidiary or associate company; then it shall have an established track record of 3 years in undertaking similar programmes or projects. In this case, the company must specify the project/programme and modalities of fund utilization, monitoring, and reporting mechanism. In addition, a company may collaborate with other companies on CSR projects/programmes; however, their respective CSR Committees must be in a position to report separately in accordance with the rules. The above rules are specified in the Companies CSR Policy Rules document (MCA, 2014b).

\subsection{Eligible Activities}

\section{The CSR Activities And Non-Compliance}

Schedule VII of the Act gives prescriptive channels for undertaking the CSR activities. Among others, it includes activities involved in dealing with issues of eradicating extreme hunger and poverty; promotion of education, gender equality, and women empowerment; reducing child mortality and improving maternal health; efforts geared towards eradication of malaria, HIV, AIDS, and other diseases; projects related to ensuring environmental sustainability, development of vocational skills, and social business projects. Besides, contributions to the Prime Minister's National Relief Fund (PMNRF) or any other fund set up by the central or state governments focusing on socio-economic development and relief, and to funds for the welfare of SC, ST, $\mathrm{OBC}$, and women fall under CSR spending. Moreover, government has prescribed quite a few specific activities through its general circular, which includes among other things, donations to academic institutions such as IIMA for conservation of buildings (MCA, 2014a).

\subsection{Restricted Activities}

All CSR activities that fall under Schedule VII must be undertaken in India alone. Companies may build CSR capacities of their own personnel and/or of the implementing agencies though institutions with established track record of at least 3 financial years. However, such expenditure is restricted to not more than 5 per cent of total CSR expenditure of the company in a financial year. The CSR policy of the company must also 
Corporate Social Responsibility, practice of observance and Spending as per the Companies...

specify that any surplus arising out of the CSR activities shall not form part of the business profit of the company. Moreover, the CSR activities that benefit only the employees of the company and their families shall not be considered as CSR activities. Furthermore, contributions of any amount directly or indirectly to any political party under section 182 of the Act shall not be considered as CSR activity.

\subsection{Penalties for Non-Compliance}

As per Section 134(8) of the Act, if a company contravenes the provision, i.e., if the Board of Directors" report does not include details about the policy developed and implemented by the company on CSR initiatives taken during the year [Section 134(3)(o)], then the company shall be punishable with fine which shall not be less than Rs. 50,000 but which may extend to Rs. 2.5 million. Moreover, every officer of the company who is in default shall be punishable with imprisonment for a term which may extend to 3 years or with a fine which shall not be less than Rs. 50,000 but which may extend to Rs. 500,000, or with both. If a company fails to spend the mandatory amount on CSR activities, it has to specify the reasons for not spending the amount; else the company and/or the officers are punishable.

\subsection{Societal Response}

\section{Perceived Response And Spending Magnitude}

Since 2009, the issue of mandatory CSR was being discussed in various forum as the Indian government began to draft and table mandatory CSR amendments to the Companies Bill in parliament. Eventually, the bill along with mandatory CSR norms became the Companies Act 2013. While the government was committed to pass the amended Act, the CSR amendments were potentially viewed to have negative impact and hence questionable in principle from a range of political views - the left, the right, and the centre. Arguing from the left of the centre, it seemed that government had abdicated its own responsibility. Instead of asking companies to spend 2 per cent on CSR activities, it could have raised corporate tax by 2 per cent, prioritized the socially beneficial activities, and spent accordingly in its own right. Arguing form the right of centre, it seemed that mandating 2 per cent expenditure was like increasing corporate tax by 2 per cent. Already a 33 per cent corporate tax in India is higher than the global average of 24 per cent. Mandatory CSR seemed to make Indian investment scenario less competitive by another 2 per cent. And, arguing from a centrist perspective, it seemed absurd to tax for CSR, for CSR is an inspirational activity which cannot mandate someone to act voluntarily (Karnani, 2013). Smaller companies which barely got covered by the new Act would have felt the impact more. In a study that employed event analysis and focused on food industry, Mehta and Deodhar (2014) showed that passing of the Act in Lok Sabha and Rajya Sabha had no impact on stock prices of food firms who get covered by the Act. Thus, stock market not responding negatively to the mandatory CSR norms was an indication that the industry stakeholders had not viewed mandatory CSR norms as coercive and a regressive measure.

\subsection{Estimates of CSR Spending}

Blending a mandatory element to what essentially was a virtuous voluntary act has given rise to an interesting issue. A recent study by Desai, Pingali, and Tripathy (2014) invokes a possibility that companies may anchor their CSR expenditures on the mandated minimum spending norms and such spending may turn out to be lower than what the expenditure would have been if there were no mandated minimum spending norms in place. That is, if some companies were spending more than 2 per cent of their net profits during the pre-Act period, now they just may become content with spending the bare minimum of 2 per cent. This may lead to lowering of expenditures and CSR activity may go down. Of course, there may be other companies not spending anything or spending much less than 2 per cent in the pre-Act period, and these companies will necessarily have to increase their CSR spending to at least 2 per cent of their net profit. The issue discussed indicates that one does not know exactly what will happen to the total CSR expenditures if the authors"e inference holds good.

An early estimate of the magnitude of the CSR spending is about about Rs. 20,000 to Rs. 25,000 crore (Rai and Bansal, 2014). This estimate, however, erroneously underestimates the CSR spending on two counts. First, it is based on a calculation of 2 per cent of the net profits after tax. Whereas, Section 198 of the Act clearly states that income tax will not be deducted for the calculation of the net profit. As per the union budget of 2015-16, the corporate tax will amount to a enormous Rs. 470,628 crore for the financial year 2015-16 (MF, 2015). Second, their estimates are based on the Prowess data provided for the financial year 2012-13. Net profit, net worth, and turnover for the current and future financial years will be much higher than the financial year 2012-13. Therefore, both on account of 2 per cent calculations on corporate tax and many more companies exceeding the net profit, net worth, and turnover criteria, the CSR spending for the current and future years will be much larger than Rs. 25,000 crore. Perhaps the time is ripe to compare and contrast the exact CSR expenditures as companies would complete filing of their returns for the financial year 2014-15 in the near future. 


\section{Channels Of CSR Spending}

The process of complying with the CSR norms and the kind of activities a company may engage in are laid out in Sections 2 and 3 above. However, these aspects do not touch upon the channels of CSR practices companies may adopt. As elaborated by Rangan, Chase, and Karim (2015); the CSR activities of a company fall into three channels of CSR practices - a) focusing on philanthropy, b) improving operational efficiency, and c) transforming the business model. Of the three, the first one can easily be related to the CSR eligible activities specified in the Companies Act 2013. In the financial year 2012-13 Persistent Systems received ET Now Award for best HR practices in CSR activities. The company"s CSR activities included, among other things, health check-ups, provision of Jaipur foot to differently abled individuals, environmental conservation, and supporting employees for volunteering in social enterprises. These activities do not in any way produce profits or improve business performance. In that sense, these are purely philanthropic activities. As mentioned in Section 3 above, even contribution to Prime Minister"s National Relief Fund (PMNRF) falls in this channel. In fact, all donations towards (PMNRF) are notified for 100 per cent deduction from taxable income under Section 80G of the Income Tax Act, 1961 (PMO, 2014).

The activities in the second channel deliver social or environmental benefits through supporting business operations throughout the value chain of the company and improve efficiency and effectiveness within the company and the society at large. For example, sustainability initiatives may reduce resource use, wastage, and emissions, which may reduce cost, improve working conditions and productivity, and provide environmental benefits to society. For example, Infosys has developed smart-building solutions that contribute to 15 per cent reduction in energy consumption. Similarly, food waste is being converted into biogas at their Pune campus and CFL crusher is being experimented at Bangalore campus to ensure that mercury in CFLs and tube lights is recycled (Bhatt, 2015).

Needless to say, companies would need to enlist independent auditing firms to evaluate such energy conserving, environmentally safe, efficient, cost saving initiatives. Further, companies would have to inform the government that as per the CSR policy rules, these activities are not done in pursuance of normal course of business of the company but in pursuance of the eligible CSR activities specified in Section 135, Schedule VII of the Act. A word of caution - this channel of CSR activities also includes assistance given to employees for healthcare, re-training, and higher educational attainment. Such activities are likely to improve a company's productivity and perhaps reduce cost. However, as per the clauses of the Act mentioned in earlier section, expenditure on employee benefits is not counted toward discharging of CSR obligation.

Let us consider the third channel of CSR practice, namely, transforming the business model. This channel involves a long-term commitment to social and environmental value creation for external stakeholders while maintaining or improving internal bottom-line targets. For example, as reported by Rangan, Chase, and Karim (2015); Jain Irrigation, a drip-irrigation-equipment making company promoted a shared-value business model between small farmers and itself. The drip irrigation technology conserves water in arid regions and increases agricultural yield due to controlled supply of water. Moreover, by facilitating micro-credit for the irrigation system, giving technical advice, and buying produce at guaranteed price from farmers, Jain Irrigation created a societal value which was also essential for its own success. For initiatives through such channels, though difficult, it is imperative that company develops measures to demonstrate societal value creation. In the case of Jain Irrigation, while farmers" income received a boost, so did profitability of the company. Of course, in the context of the Companies Act 2013, it will be a challenge to convince the government that such initiative was not a part of the normal course of business and that it could qualify for CSR activities as per the Act. The other challenge would be to measure the extent of value creation through such activities. Perhaps the CSR norms of the Act may evolve as time progresses and there would be scope to include activities from this channel in Schedule VII. In any case, companies that believe in creation of shared value and want to align their business interest with CSR activities would not mind continuing with what they think is right, provided they also pass the 2 per cent test of the Act through some other activities.

\section{Concluding Comments}

With a beginning of Companies Act 2013 corporate aid has been blended with a mandatory element in it. Now, companies that get covered under the new Act must form CSR Committees from among the Board members, form CSR policies, and announce, execute, and monitor their CSR activities. If companies fail to do so, penalties are also in place. It was felt that industry may view imposition of the provision as coercive, impinging on profitability and hence on stock prices. However, event analysis conducted on big and small food companies shows that imposition of the CSR provisions has had no negative impact on stock prices.

There is another apprehension - a study invokes the possibility that if firms were spending more than 2 per cent of net profits during the pre-Act period, they may now anchor their spending on the legal requirements and become content with spending only 2 per cent of net profit in the post-Act periods. However, there must be scores of other companies which were spending nothing or much less than 2 per cent of their net profits in the 
pre-Act period. They will now have to spend the mandatory minimum amounts. Thus, one does not know if the total amounts spend would increase or decrease as a result of implementation of the Act. An early study on the magnitude of CSR expenditures places the estimate between Rs. 20,000 crore to Rs. 25,000 crore. However, the magnitude is underestimated, for the 2 per cent norm is applied to profit-after-tax, which, as per the Act should have been applied to net profit before tax. Moreover, the calculations are done for a dated period - financial year 2012-13. The current and future net profits, net worth, and turnovers must be much higher than what they were in 2012-13 period. Perhaps time is ripe to compare and contrast these issues as companies successfully complete their tax filing for the 2014-15 financial year very soon.

While the Act specifies the kind of activities companies could undertake to comply with the CSR norms, it does not talk about the channels through which these activities can be undertaken. First channel is the philanthropic activity which can be easily related to the CSR activities listed in the Schedule VII. The second channel is related to improving operational efficiency of the company through various activities that reduce resource use, wastage, and emissions, which may reduce cost, improve working conditions and productivity, and provide environmental benefits to society. Expenses towards such initiatives can be classified under various activities listed in Schedule VII. Assistance given to employees for healthcare, training, and education also has potential to increase operational efficiency of firms. However, as per the Act, such expenditure is not counted toward discharging of CSR obligations.

Some companies may come up with new models of business that create a shared value for external stakeholders. Such models may increase profits and productivity for the companies and other external stakeholders and also generate practices that are environmentally safe and sustainable. However, it will be a challenge to establish that such initiatives of the companies can be counted towards discharging of the CSR activities that fall under Schedule VII of the Act. The challenge would be to establish and measure the value creation and apportion expenses that went into these efforts, and, show that the activities of the new business model were not their normal course of business. Perhaps it will be difficult to make that connection at this stage. Until then, enlightened companies that believe in creation of shared value and want to align their business interests with CSR activities would not mind continuing with what they think is right. The third channel initiatives hopefully will open up activities in first two channels which would qualify for the mandatory 2 per cent test.

[1] Bhatt, B. (2015). Indian Corporate Citizenship: Myth or Reality?, a report prepared by Mr. Bimal Bhatt, Chartered Accountant, Vadodara, India.

[2] Desai, N., Pingali, V., and Tripathi, A. (2015). "Is 2\% the Solution?: Experimental Evidence on the New CSR Rule in India," Indian Institute of Management Ahmedabad (IIMA) Working Paper No. WP2015-03-09.

[3] MCA (2013). The Companies Act, 2013; accessed on 22/5/2015 from website of Ministry of Corporate Affairs at http://www.mca.gov.in/Ministry/pdf/CompaniesAct2013.pdf

[4] MCA (2014a). General Circular No 21/2014; accessed on 22/5/2015 from Ministry of Corporate Affairs website at http://www.mca.gov.in/Ministry/pdf/General_Circular_21_2014.pdf

[5] MCA (2014b). Notification, dated 27/2/2014; accessed on 23/5/2015 from Ministry of Corporate Affairs website at http://www.mca.gov.in/Ministry/pdf/Companies Act Notification2_2014.pdf

[6] Karnani, Aneel (2013). Mandatory CSR in India: A Bad Proposal," Stanford Social Innovation Review, May 20, retrieved from http://www.ssireview.org/blog/entry/mandatory_csr_in_india_a_bad_proposal

[7] Madgaonkar, G.N. (1863). "Mumbaiche Varnan" (Commentary on Mumbai), Saket Prakashan: Aurangabad. Murali Ranganathan"s translation of this book from Marathi to English titled Govind Narayan"s Mumbai is published by Anthem Press in 2008.

[8] Mehta, F. and Deodhar S. (2014). “Assessing Impact of Mandatory CSR on Food Industry,” Indian Food Industry, Vol. 33(6), pp. 29-36.

[9] Rai, S. and Bansal, S. (2014). "An Analysis of Corporate Social Responsibility Expenditure in India," Economic and Political Weekly, Vol. XLIX(50), December 13.

[10] MF (2015). "Receipt Budget," Union Budget 2015-16 published by Ministry of Finance (MF), accessed on 25/5/2015 from the website http://indiabudget.nic.in/ub2015-16/rec/tr.pdf

[11] PMO (2014). "Prime Minister"s National Relief Fund - Reg.," letter dated 20/8/2014 accessed on 26/5/2014 from http://taxguru.in/wp-content/uploads/2014/09/Prime-Ministers-National-Relief-Fund-4-9-2014.pdf 